\title{
Documentação
}

\section{O testamento que validou José Eduardo dos Santos na presidência de Angola em 1979}

\author{
Patrício Batsîkama \\ Historiador \\ FCS/Universidade Agostinho Neto
}

\section{Introdução}

Nas minhas andanças em Luanda e outras sedes provinciais de Angola tenho notado que a maior parte da juventude desconhece a participação de José Eduardo dos Santos na luta de libertação de Angola. O apelo dos kotas segundo o qual o atual presidente "sacrificou a sua juventude" não é bem percebido pela juventude: entrevistei, em sete cidades diferentes ${ }^{1}$, cerca de 312 jovens entre 18 e $23 \operatorname{anos}^{2}$, dos quais $238^{3}$ acham que seria apenas falácia dos kotas, pois somente a palavra deles não bastaria. A ruptura kotas/kandengues pareceu-me enorme, pela falta de transmissão da experiência [socialização]. Isso é um problema sério para qualquer sociedade, e Platão já prescreveu isso na sua obra República.

De forma breve, apresento o quadro da juventude entrevistada por mim.

1 As cidades são: Luanda: 198; Uige: 12; Mbânz’a Kôngo: 12; Malange: 11; Lubângu: 29; Benguela: 31 ; Ondjiva: 19. Fiquemos questão de escolher apenas os estudantes entre $10^{\mathrm{a}}$ classe de Ensino Médio até $3^{\mathrm{o}}$ ano do Ensino superior. A maioria é crente: 62 católicos; 39 protestantes; 124 tokoistas. 87 restantes não pertence a nenhuma religião. As minhas entrevistas eram seletivas.

2 Esta recolha relaciona-se com o trabalho da minha Tese de Douramento.

3181 oriundos de Luanda; Uige: 6; Mbânz'a Kôngo: 9; Malange: 2; Lubângu: 17; Benguela: 11; Ondjiva: 12. As idades são entre: 18 e 23 anos; habilitações literárias: 10 classe e 2 anos de frequência universitária. 


\begin{tabular}{||l||l||l||l|l||l||l|l||}
\cline { 2 - 7 } \multicolumn{1}{c|}{} & \multicolumn{9}{c||}{ Províncias percorridas } \\
\cline { 2 - 8 } \multicolumn{1}{c||}{} & Benguela & Luanda & Lubangu & Malange & MbanzaK & Ondjiva & Uige \\
\hline \hline $18-19$ anos & 7 & 41 & 7 & 4 & 3 & 2 & 2 \\
\hline $20-21$ anos & 11 & 62 & 12 & 5 & 4 & 4 & 1 \\
\hline 22-23 anos & 13 & 95 & 9 & 2 & 5 & 13 & 9 \\
\hline Total: & $\mathbf{3 1}$ & $\mathbf{1 9 8}$ & $\mathbf{2 9}$ & $\mathbf{1 1}$ & $\mathbf{1 2}$ & $\mathbf{1 9}$ & $\mathbf{1 2}$ \\
\hline
\end{tabular}

Poder-se-á notar que as províncias orientais angolanas (Moxico, Lunda Norte; Lunda Sul...) estejam ausentes na grelha das províncias percorridas. $\mathrm{Na}$ verdade, por falta de recursos não consegui lá estar. Mas para solucionar esse impasse, fiz questão de, em Luanda, selecionar indivíduos oriundos de algumas províncias como: Moxico $=19$ entrevistas; Lûnda Norte $=11$ entrevistas; Lûnda Sul: 8 entrevistas; Kwându Kubângu = 6 entrevistados. ${ }^{4}$

Realizam-se em Luanda, desde há algum tempo, várias atividades extra-acadêmicas abordando a "Vida e obra do Eng. José Eduardo dos Santos” com muita pompas publicitárias. A conotação política destas atividades é reprovada por uma parte da juventude angolana que associa isso ao culto de personalidade. Isso pode perigar a historicidade dos factos, se não for bem discernidas as coisas. Dai, a razão deste texto acompanhado de documentos [submetidos à análises, também] relevantes.

O presente artigo tentará responder a duas perguntas concatenadas: (1) será que haveria alguma razão específica para o Comité Central do MPLA eleger José Eduardo dos Santos como substituto de Dr. Agostinho Neto à presidência da RPA em Setembro 1979? Qual seria? (2) Será que, assim acredita a maior parte da juventude, Dr. Agostinho Neto [anterior presidente da república de Angola] terá deixado um testamento para a sua substituição?

Para alcançar este objectivo, preparei cinco pequenas perguntas, além de, na ficha para recolher as informações, constar as informações sobre os dados demográficos (idade, função, religião, naturalidade) dos inquiridos:

(1) Que importância teriam as atividades sobre "Vida e obras de José Eduardo dos Santos", a realizar-se em todo país?

(2) Que informações que tens com relação a participação do presidente José Eduardo dos Santos na Luta pela Libertação de Angola?

4 (1) Moxico: 3 entrevistas de 18-19 anos; 4 entrevistados de 20-21 anos; 12 entrevistados de 22-23 anos; (2) Lûnda Norte: 2 entrevistados de 18-19 anos; 4 entrevistados de 20-21 anos; 5 entrevistados de 22-23 anos; (3) Lûnda Sul: 1 entrevistado de 19 anos; 5 entrevistados de 20-21 anos; 2 entrevistados de 23 anos; (4) Kwându Kubângu: 1 entrevistado de 18 anos; 4 entrevistados de 20-21 anos; 1 entrevistado de 22 anos. 
(3) Quais foram as razões que levaram José Eduardo dos Santos a ser designado presidente da república de Angola em 1979? O que lhe foi contado pelos mais velhos?

(4) Na sua opinião, o que achas da eleição do presidente José Eduardo dos Santos em 2012? Como viveu essa experiência?

(5) Como jovem angolano, o que pediria ao presidente da república caso lhe fosse dado essa oportunidade?

A primeira pergunta tinha um só propósito: tentar saber quanto a vida pública de Angola interessa a juventude [Angola de amanhã].

A segunda e terceira perguntas consistiam em saber se os instrumentos da socialização em Angola funcionam bem, principalmente a Escola e a Educação Popular [massiva]. Também, interessava-me perceber a reação (dissimulada ou visível) da população juvenil perante a mega publicidade sobre a figura do presidente da república em Agosto de 2014. Também, interessavamme saber a atitude dos jovens (apenas os estudantes) face aos depoimentos públicos [dos políticos, sobretudo] com relação a ilustre figura do presidente angolano acutal.

A quarta questão tinha um intento especial. Para os jovens que votaram em 2012, tentava eu perceber qual terá sido a sua sensação às eleições que participaram a experiência tiveram, e se o voto valeu alguma coisa com os resultados. Para aqueles que não votaram, saber como interpretaram aquele momento e o que esperam nas próximas eleições universais. Buscava eu, com estas perguntas, decifrar os sentimentos dos entrevistados para enquadrar melhor as respostas fornecidas anteriormente. Daí, a quinta pergunta cuja resposta foi pronta e unânime: [bom] emprego, casa própria e [bom] carro.

As respostas as estas perguntas não foram muito animadoras. Para além de apresentar problemas do mal aproveitamento escolar dos nossos alunos e estudantes, a falta de leitura e a ausência de livros $^{5}$ que abordam com seriedade e clareza esta figura [e outras] fazem faltam. Com relação a primeira pergunta, 207 acham que é bajulação ao passo que apenas 39 percebem a importância de saber mais sobre o seu presidente. Encontrei apenas três respostas certeiras [em Luanda apenas] com relação à segunda pergunta. 52 preferem não responder, ao passo que 11 respondem pelas gargalhadas seguidas da frase: "podes passar" ou "isso não, prof." ou ainda "estou

5 Quero dizer com isso: (1) livros didáticos especializados sobre as figuras históricas em geral; (2) bibliotecas municipais [educação popular] que providenciem estes materiais; (3) programas escolares ligados aos museus, bibliotecas, etc.; (4) ausência de centro culturais, e onde eles existem, dificilmente se nota dinamismo, pois os responsáveis se queixam de falta de verbas, condições técnicas, logísticas, etc. 
sem palavras", "sem comentário", etc.

301 respostas com relação a terceira pergunta animaram-me: os jovens entrevistados acham que Dr. Agostinho Neto deixou um testamento designando José Eduardo dos Santos como seu sucessor. As explicações que fornecem pareceram-me a reinvenção da memória. Estas respostas animaram-me porque eu vivi o mesmo mito fora de Angola, antes de reencontrá-lo nas ruas de Luanda e mesmo em espaços acadêmicos no país.

As respostas recolhidas na quarta pergunta indicam três aspectos: (i) muitos dos jovens entrevistados que votaram, fizeram-no em nome da moda e pela euforia do momento; (ii) aqueles que não o fizeram nutrem-se de inúmeras expectativas; (iii) uns acham que o voto é exprimir a vontade popular, mas quase todos pensam que o voto não resolve os seus problemas porque o voto não fala!

Com relação a quinta pergunta: todos querem emprego e boas condições sociais de vida.

Começarei por tentar mostrar - documentalmente - a presença do independentista José Eduardo [dos Santos] na mira da PIDE/GDS e, no fim, fazer uma síntese dos documentos da realização da Assembleia Regional Extraordinária do MPLA em 1972 onde acho que os resultados [daquelas atividades] terão repercutido na sua indicação em 1979 como substituto possível de Dr. Agostinho Neto. Talvez com estes documentos, se pensa já na seguinte hipótese, que tentarei verificar: será a Assembleia Regional Extraordinária de 1972 algum "testamento virtual” que a memória reinventou a ponto de muitos jovens assim acreditarem.

Ao longo deste artigo tentarei mostrar a importância desta Assembleia, reunir as evidências que mostrassem como, paulatinamente, a figura de José Eduardo dos Santos aproximou-se a de Agostinho Neto na liderança do MPLA, e mais tarde do Governo onde ocupou as funções ministeriais estratégicos e de poder real. ${ }^{6}$

\section{Estudante de Minas em Bakou}

6 Ministro do Planeamento; Ministro das Relações Exteriores. 


\subsection{Lista nominal de Estudantes independentistas}

Tive acesso alguns documentos que encontrei nos arquivos da PIDE-DGS e Fundação Mário Soares: são listas nominais dos estudantes de Angola que se formavam nos países socialistas da Europa de Leste [e Cuba]. E a PIDE-DGS acompanhava-os.

No Doc.\#1b [ver infra: página 29], a lista nominal dos estudantes perseguidos pela PIDE, encontra-se em quinta posição [e sublinhado] o nome de "DOS SANTOS, José Eduardo", membro do MPLA e estudante em Bakou.

Importa chamar atenção sobre a maneira como os serviços secretos de Portugal colonial identificam-no neste documento: DOS SANTOS em maiúscula e José Eduardo em minúscula. Supõe-se que DOS SANTOS seja o apelido. José Eduardo é o primeiro nome [José sendo o nome de batismo].

Nos outros documentos da PIDE encontra-se também um outro militante do MPLA com nome de EDUARDO DOS SANTOS (veja o Anexo\#2a; \#2b), que é preciso não confundir com José Eduardo (veja o Doc. \#5). O primeiro era médico, ao passo que o segundo é engenheiro em minas e formado em Bakou [as vezes com a grafia de Bacu: Doc.\#4].

É muito provável que o nome completo do médico seja Eduardo Macedo dos Santos: neste caso Eduardo seria nome de batismo. De acordo com alguns dos seus companheiros, e a nossa modesta consulta arquivística prova-o, ele é chamado de Eduardo dos Santos. As vezes, Macedo aparece. Há quem diga que tinha também o nome de José Eduardo Macedo dos Santos, o que documentalmente ainda não encontrei, nas minhas humildes e limitadas buscas. Curioso ainda é ver que os veteranos de guerra que lá estiveram especificam que o nome de José é do atual presidente angolano. Em alguns discursos, o atual chefe de Estado chama-o Dr. Eduardo Macedo dos Santos. O que está patente de forma clara é que José Eduardo - em todos documentos verificados por mim - é o engenheiro formado em Baku. Também, importa realçar que a partir de 1965, o médico Eduardo dos Santos tinha ficado fora do Comité Diretor do MPLA, por razões claramente conhecidas (A.F.M.S; Torre do Tombo: PIDE/DGS). De 1965 adiante José Eduardo ou Eduardo dos Santos é, de acordo com os arquivos consultados por mim e comparação que fiz com alguns depoimentos dos antigos combatentes, o atual presidente de Angola.

Nesta lista nominal encontrei nomes de alguns dirigentes ainda vivos e no ativo do MPLA. 
A PIDE-DGS tem várias listas nominais dos independentistas angolanos onde figura o nome de José Eduardo dos Santos [nas suas variantes] classificados em diferentes caixas ora do MPLA, ora de Dr. Agostinho Neto. Mas dispõe também de apenas um pequeno ficheiro [caixa] reservado em José Eduardo dos Santos. ${ }^{7}$

O arquivo da Fundação Mário Soares é interessante, e nele constam também documentos com nome de José Eduardo assim como outros arquivos. Isso leva-nos a considerar alguns $\operatorname{aspectos}^{8}$, que aliás, nos permitam perceber a importância dos documentos que aqui reproduzo.

7 Notei que em alguns dos documentos nas outras caixas relacionadas ao MPLA e Agostinho Neto onde consta o nome de José Eduardo dos Santos ou simplesmente Eduardo dos Santos. Cheguei a sugerir verbalmente e via e-mail a Pedro Vasconcelos da A.N.T.T. que se possa oxigenar/volumar a pasta específica de José Eduardo dos Santos com aqueles documentos. Objectivo: facilitar a busca.

8 As informações da PIDE/DGS não são isoladas, mas antes confrontadas com as demais informações. Vários agentes da PIDE/DGS davam as possíveis variantes de informações sobre determinadas pessoas ou determinados assuntos. E estas variantes de informações eram analisadas. Os SCCIA, ao seu turno, tinha como missão de estudar várias informações, distribuí-las por secções e limitar apenas na gestão da informação correta (vista que havia contrainformação na parte dos independentistas, também). O terceiro aspecto era a forma como o Ministério Ultramarino tratava as informações: apesar de receber informações já averiguadas (pela PIDE/DGS ou SCCIA) dispunha dos seus agentes especializados a quem foram enviadas informações para identificar as fontes, seus detentores e os veículos das mesmas. 


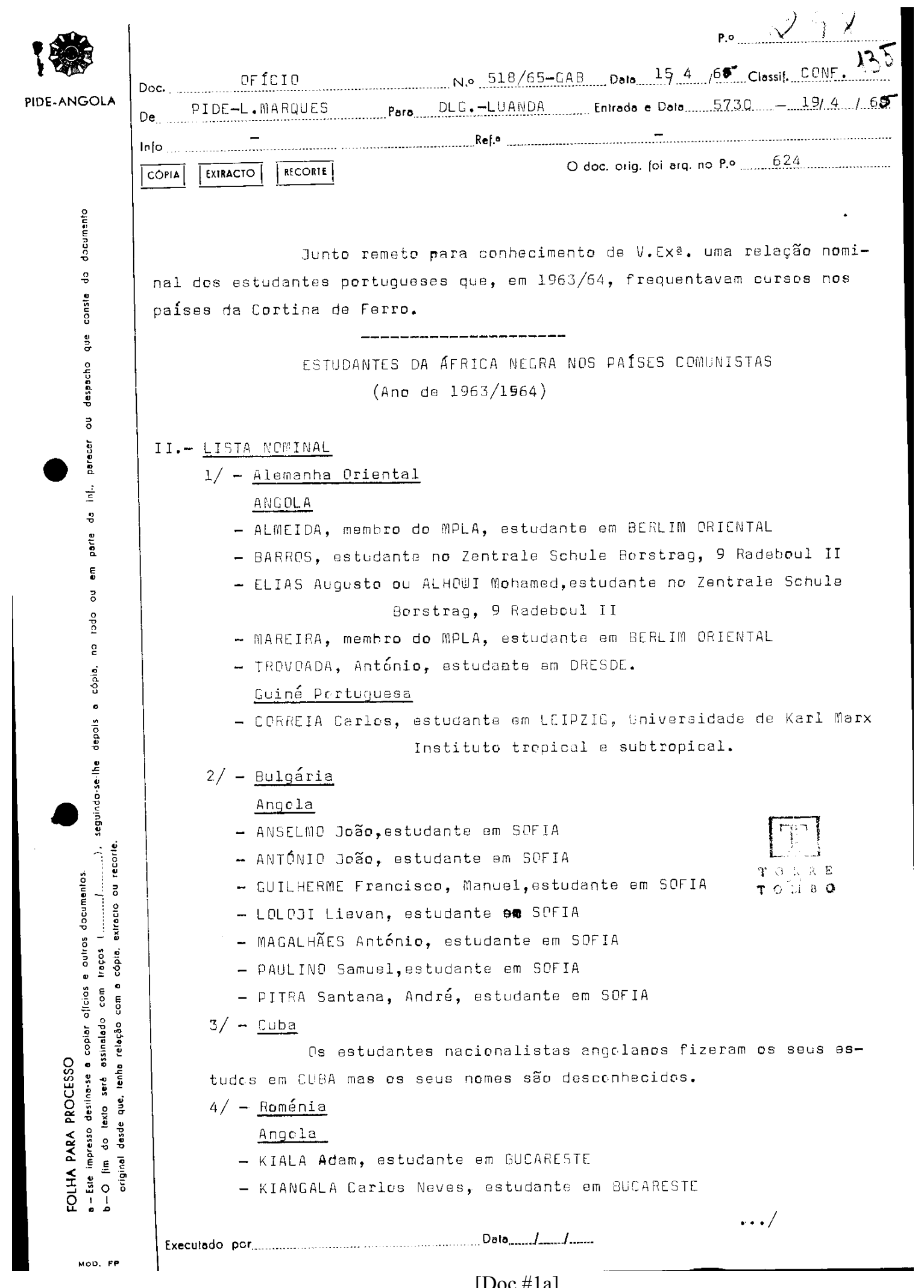

[Doc.\#1a] 


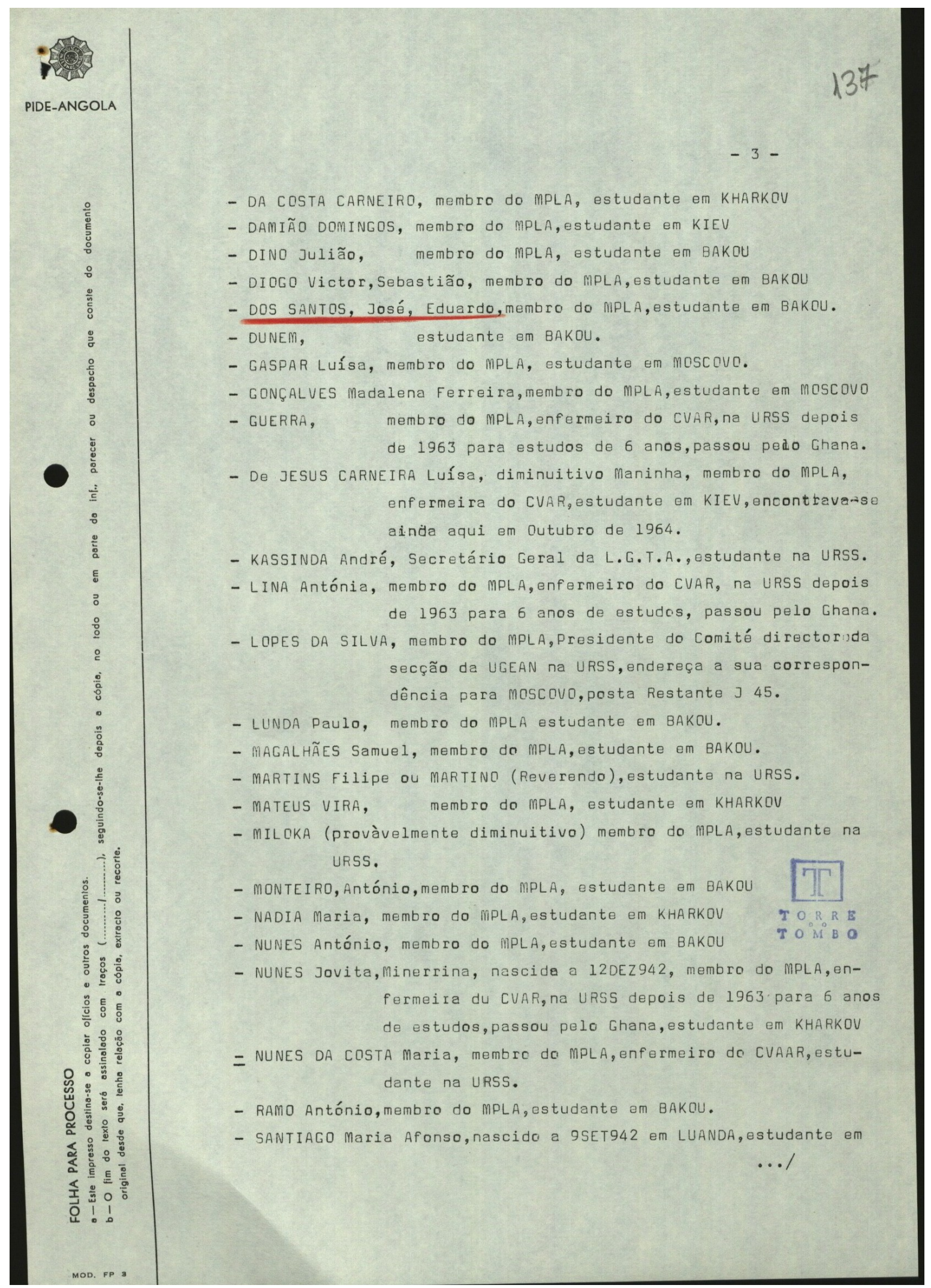

página 137 [Doc.\#1b] 


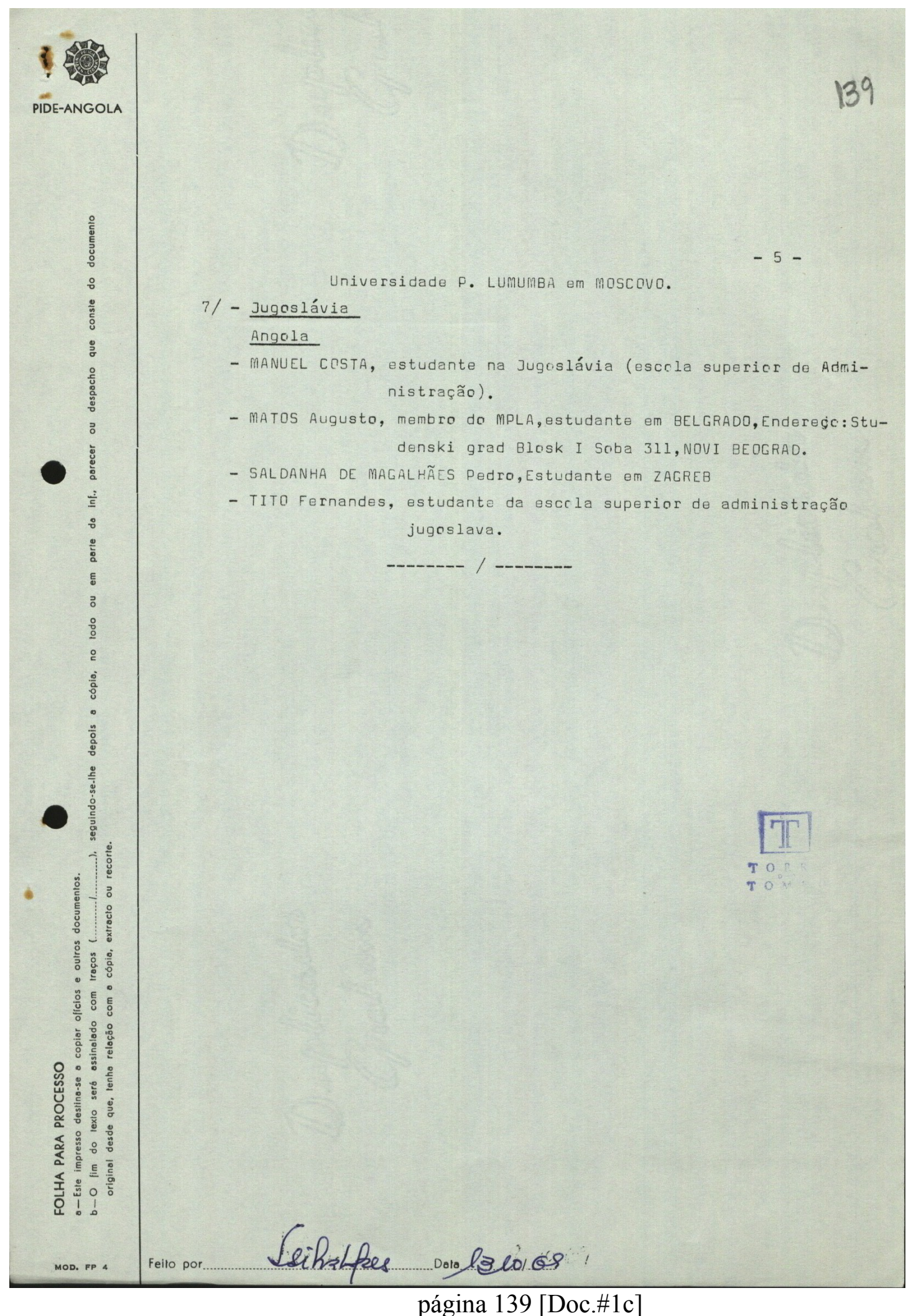

Esta é a última página do documento nominal dos estudantes africanos nos países 
comunistas.

\section{Outros documentos sobre os militantes do MPLA}

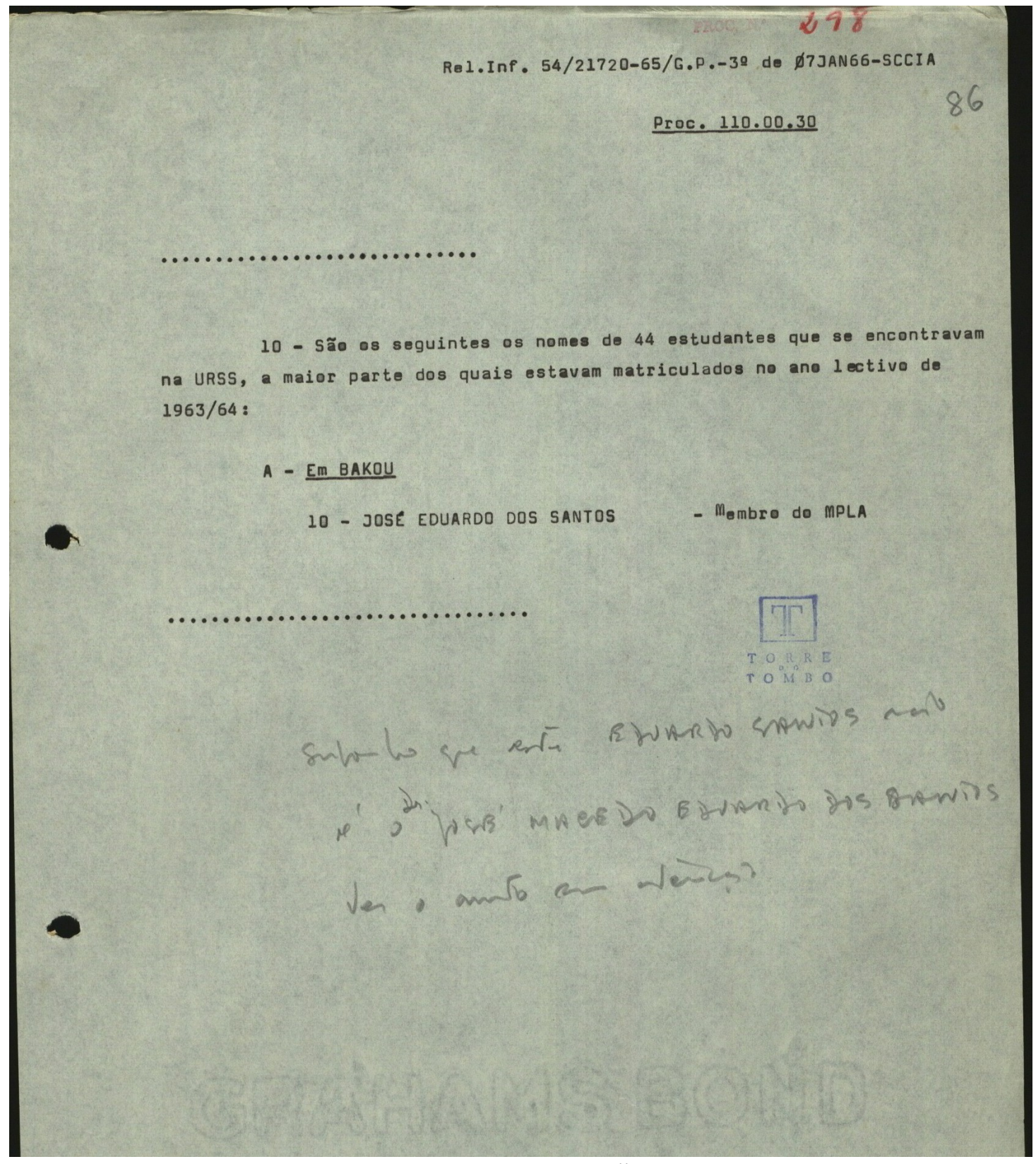

[Doc.\#2]

Há dois aspectos que é preciso assinalar aqui para perceber este documento [Doc.\#2]:

(i) Em Bakou havia vários estudantes, mas aqui é apenas destacado uma só pessoa.

O presente documento consistia na Informação $n^{\circ}$. 54/21720-65/G.P.-3 ${ }^{\circ}$ do 
processo 110.00.30: o documento em si associa-se a um dossier individual (ofício 1544/66-RS-2a). Apenas líderes ou pessoas capazes de mobilizar multidão parecem ter ficheiros individuais com anexo de vários outros documentos de informações adicionais [ver: Docs \#3; \#4 e \#5]. Prova disso é o Doc.\#5 onde ainda são legíveis os nomes dos seguintes dirigentes ${ }^{9}$ : Daniel Júlio Chipenda, Maria Mambo Café, Augusto João Borges e José Eduardo.

Em 1966, ano que foi produzido este documento acima referido, Congo Kinsâsa e Congo Brazzaville [e Zâmbia em 1970/73] eram duas plataformas geoestratégicas mais próximo e de extrema importância na região que simbolizavam os poderes de Washington e de Moscovo [em disputa]. A figura de José Eduardo dos Santos já era conotado como um dos suspeitos capaz de dinamizar a guerrilha na $\mathrm{I}^{\mathrm{a}}$ e $\mathrm{II}^{\mathrm{a}}$ Região do MPLA. Os documentos anteriores e posteriores as atividades de 9-16 de Abril de 1972 apresentam as primeiras evidências [ver infra: capítulo III] e vários autores perceberam disso depois (Conceição, 1999; Malhazes, 2009; Shubin, 2008).

Escolhi estes documentos por dois motivos. Primeiro: o movimento independentista angolano é pormenorizadamente conhecido pela PIDE/DGS a partir das fontes bem verificadas. A origem, as habilitações literárias e influências políticas dos líderes foram as questões que foram cautelosamente estudadas pelos especialistas da PIDE/DGS. José Eduardo dos Santos termina a sua formação acadêmicas em Junho de 1968, e em Agosto/Setembro estará em Brazzaville, com patrocínio dos soviéticos. As relações Kinshasa/Lisboa precisavam desta valiosa informação por causa da afinidade ideológica americana. Segundo: o palco de Congo Brazzaville ${ }^{10}$ era, do ponto de vista geoestratégico, a conquista do comunismo na África centro-meridional que se completaria com Angola. O poder de Washington ainda desconhecia que Kremlin mapeava a guerra fria em África, com Angola especificamente (Stockwell, 1979; Sá, 2011; Shubin, 2008; Milhazes, 2009). A sua vez, MPLA tinha-se consciencializado de que: "Angola, [era] chave da Libertação da África Austral"

9 No próprio documento, eles são chamados de dirigentes.

10 No dia 30 de Março de 1971, o Serviço de Centralização e Coordenação de Informação do governo colonial português informava a presença no Congo Brazzaville, do Reverendo Domingo da Silva, do diplomata Paulo Teixeira Jorge do MPLA e Justin Lekounzou e o capitão Denis Sassou Ngouessou do R. Congo [Brazzaville]. As negociações entre os dois polos consistiam na preparação humana para oxigenar a guerrilha a partir deste país já independente. (A.N.T.T.: caixa 239, fl. 212). 
(A.F.M.S.: 04317.001.007).

Outros documentos que indicam a presença do independentista José Eduardo dos Santos ${ }^{11}$ noutros espaços não interessam tanto o meu limitado trabalho que preze no facto de que Congo Brazzaville ter-se-ia o seu "bastião" onde ele conquistou a conspicuidade perante os militantes quer para a elite partidária, quer para as massas quer para comunidade internacional. ${ }^{12}$ Será por isso que focarei a Assembleia de Dolisie em 9-16 de Abril de 1972.

11 Várias caixas na Torre de Tombo indicam a presença do atual chefe de Estado angolano. Aconselhamos as caixas da PIDE/DGS e da SCCIA: caixas: 238, 235, etc.

12 SCCIA, "Apoio da Rússia ao MPLA", cota atual: Pr. Inform. n. 39; SCCIA, "MPLA - Diversos", Cota atual: proc. Infor. N ${ }^{\circ} 18$, Caixa n” ${ }^{\circ}$ 232; SCCIA, "MPLA - Obtenção de material de guerra", Cota atual: proc. Infor. n. ${ }^{\circ}$ 47. Pode também consultar o Arquivo da Fundação Mário Soares. Com relação aos livros, aconselhamos: Conceição, 1999; Shubin, 2008; Milhazes, 2009. 


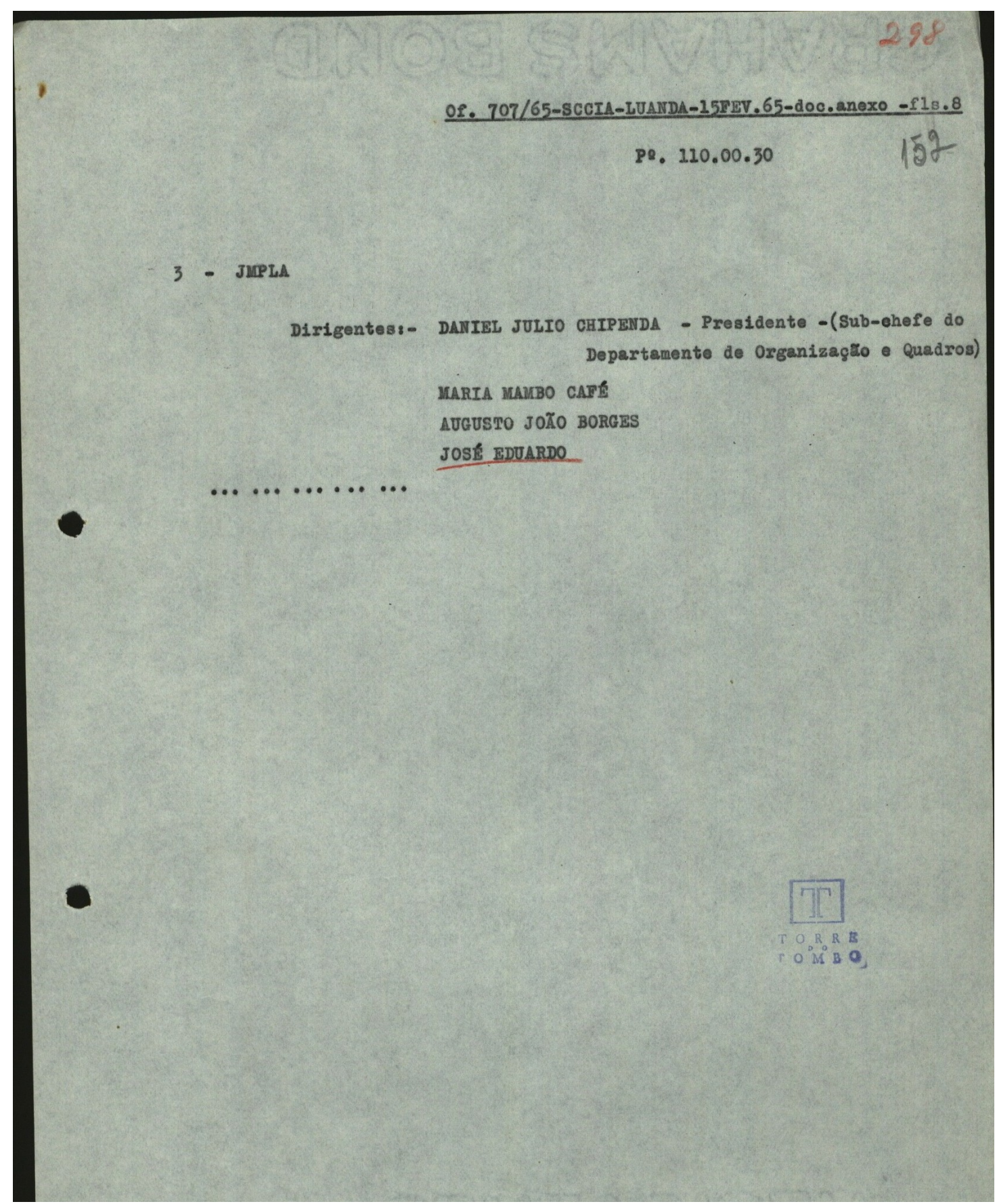

[Doc. \#3]

Documento que segue [Doc.\#4] faz parte do relatório de 18 de Março de 1970. Este documento interessa-nos por informar sobre a presença do independentista José Eduardo em Brazzaville no mês de Setembro de 1968. Quer dizer, logo depois de terminar os seus estudos acadêmicos em Junho de 1968. 


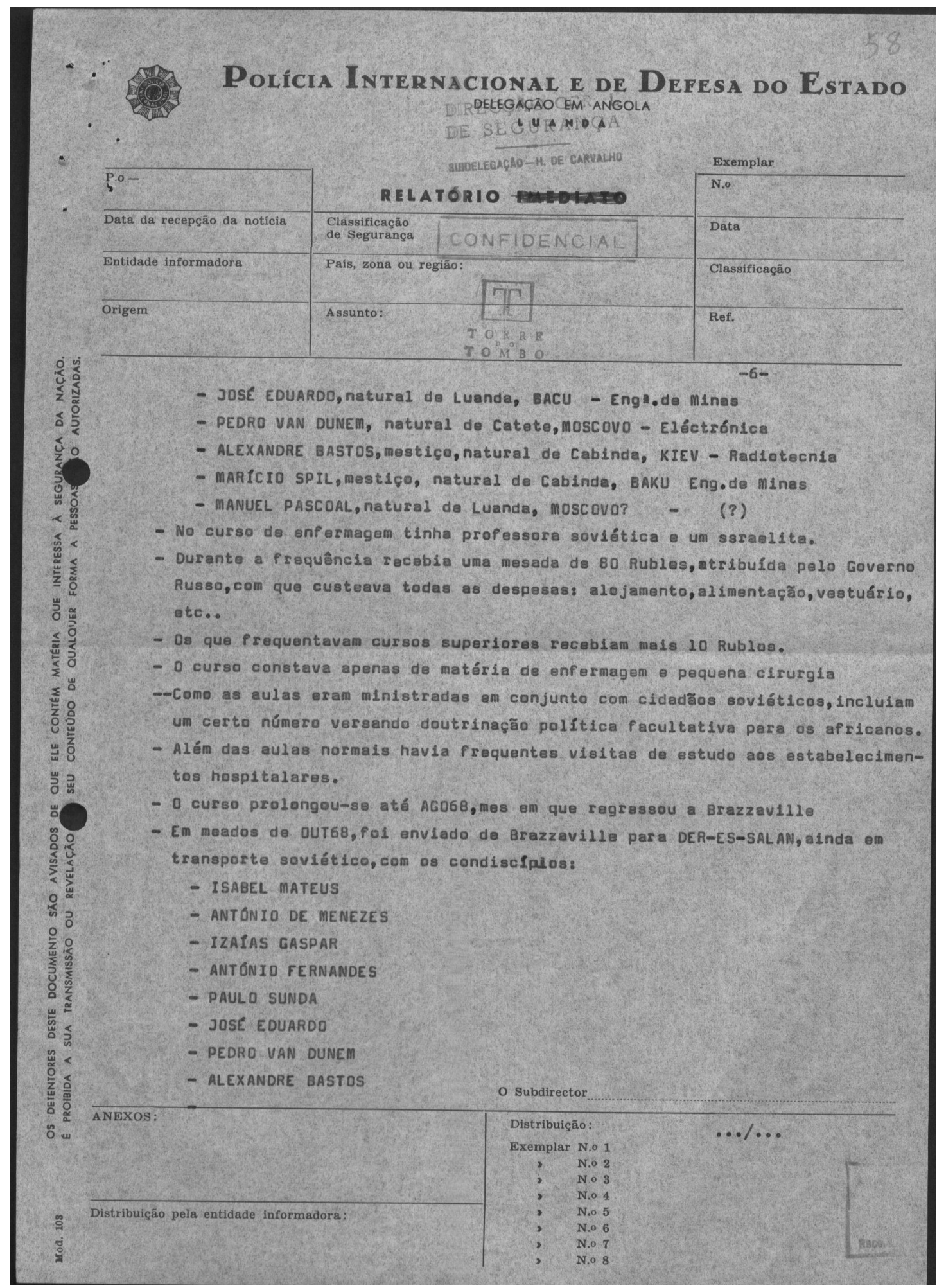

[Doc.\#4]

Trata-se de uma lista nominal que apresentava o capital humano que o MPLA dispunha nesta data [18/03/1978], de acordo com os serviços secretos de Portugal: nome, local de nascimento, país de formação e a especialidade. Apenas escolheu-se aqui a página que interessa a 
minha reflexão.

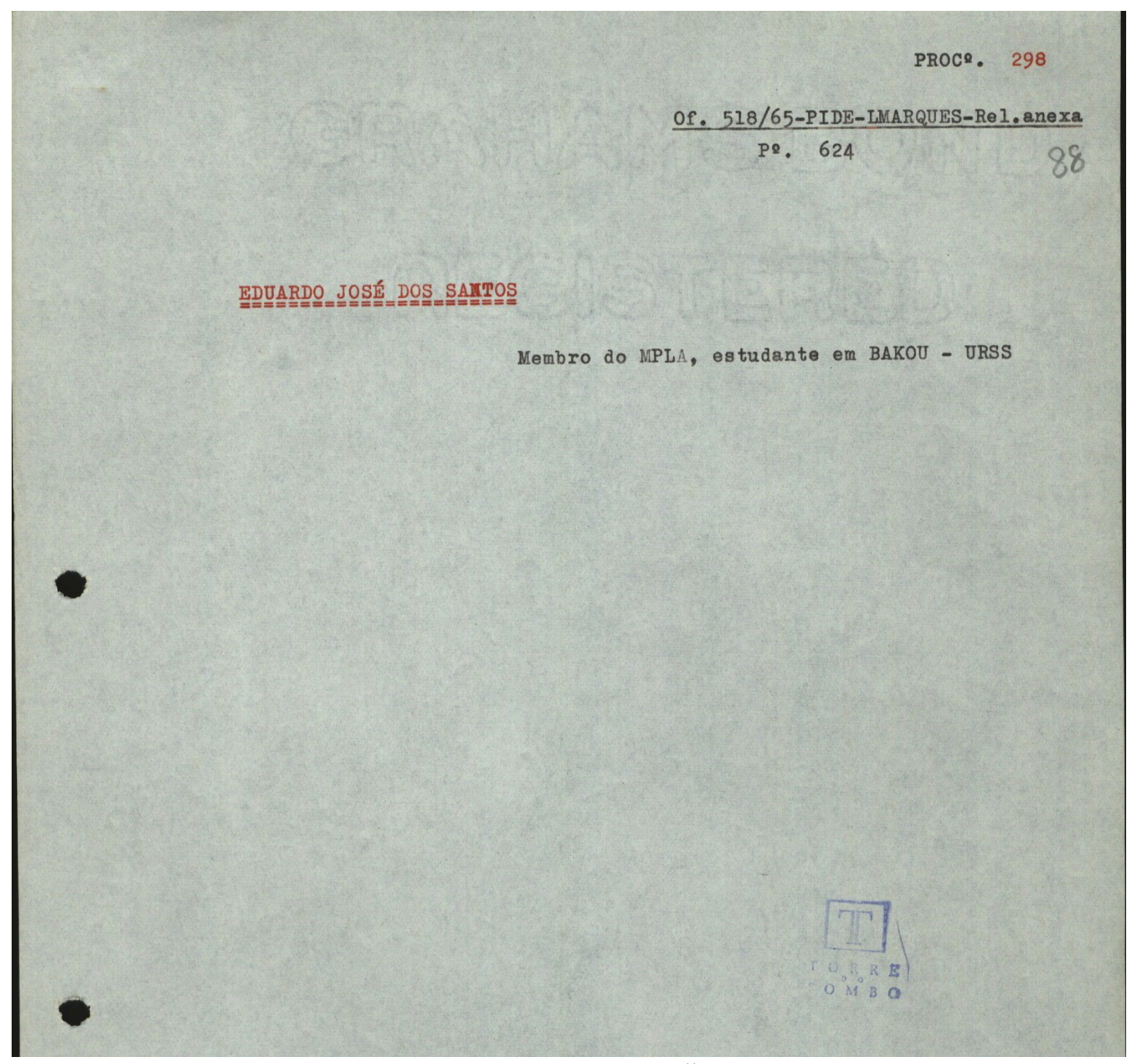

[Doc. \#5]

3. Assembleia Extraordinária Regional de Dolisie em 1972

\subsection{Antes da Assembleia}

No arquivo da Fundação Mário Soares, na pasta n. ${ }^{\circ} 04317.001 .017$ encontramos interessantes cartas em duas línguas [portuguesa e francesa] da autoria de diferentes militantes do MPLA. Elas abordam temas interessantes, como: racismo, tribalismo, divisões internas, etc. Destas 
preocupações, resultaria a Assembleia Extraordinária Regional.

Mas antes disso convinha recuar bocado no passado: no dia 1 de Abril de 1970, o presidente do Comité Diretor - Dr. Agostinho Neto - assinava a Ordem de Serviço 8/70, cujo teor foi o seguinte:

"São nomeados membros do Comité de Coordenação Político-Militar, criado pela Ordem de Serviço n. ${ }^{\circ}$ 6/70, de 20 de Fevereiro de 1970, os seguintes membros efectivos do Comité Directo:

(1) Camarada IKO [Henriques Tales Carreira];

(2) Camarada Monimambo;

(3) Camarada Sango;

(4) Camarada Tchiweka [Lúcio Lara].

Lusaka, 01 de Abril

O Presidente do Comité Director

Dr. Agostinho Neto".

(A.F.M.S: pasta, \#04317.001.011).

Esta coordenação político-militar tinha, entre outras, a missão de mapear a capacidade humana existente, estimar as vontades e motivações locais assim como a disponibilidade logística e propor estratégia de lançar uma guerra com cobertura nacional sobre a Libertação de Angola.

A situação geográfica da Zâmbia e nos contextos econômicos de 1968-1973 não permitiu as autoridades daquele país arriscar algum embargo dos seus patrocinadores, nem lhes interessou perder boa vizinhança com os países que têm acesso ao mar. A titulo de exemplo, a Zâmbia sempre precisou do caminho de ferro de Benguela, e com isso evitar toda corte na parte do governo colonial português e dos E.U.A.

A Namíbia ainda era cedida primeiro a ONU e depois ao governo sul-africano cuja política não compactuava com os ideais do MPLA.

O Zaire de Mobutu - país com qual Angola partilha perto de $2600 \mathrm{~km}$ de fronteira (Batsîkama, 2014c) - era o palco americano. Já nos tempos de Kasa-Vubu [1962] a instalação do MPLA foi diplomaticamente negada pelo concurso da FNLA. ${ }^{13}$

13 O meu avô paterno, Raphael Batsîkama - antigo secretário-geral de ABAKO - explicou-me que nos anos 19501960, os comerciantes angolanos zômbo contribuíram (indicando-me o meu avô materno que era comerciante) sobremaneira para Congo Kinsâsa alcançasse a sua independência. O meu avô Vatûnga Miguel, muzômbo de Kibokolo, explicou-me que os Bazômbo [angolano em geral] apoiavam por duas razões: (i) solidariedade com o povo de Congo belga que os acolheu; (ii) esperavam que o Congo Kinsâsa independente viesse ajudar Angola a liberta-se da colonização portuguesa. Ora, FNLA era tida pela OUA, com patrocínio de Nkwame Nkrhuma, como o principal 
Apenas Congo Brazzaville (Batsîkama, 2014c) tinha um regime de inclinação socialista. Lúcio Lara (Tchiwaka) e Henriques Teles Carreira (Iko Carreira) lançaram-se para Brazzaville, depois desta Ordem de Serviço e outras imperativas da guerrilha, com propósito de radiografar e oxigenar as I ${ }^{\mathrm{a}}$ e II $^{\mathrm{a}}$ Regiões do MPLA.

interlocutor do povo angolano. No meu artigo, tento explicar o nacionalismo congolês (dos dois Congo): Batsîkama, 2014c. 
Sankofa. Revista de História da África e de Estudos da Diáspora Africana Ano VII, NºXIV, Dezembro/2014

DOSSI" ORGANISATION

ORDEM DE SERVIC, N: 8170

Saio nomeadss members to conite' it CODRDEVICTÁ POCITICO. RILITAR, Criads wele ondan de tericico hi 6/70, de 20 er fevereino a 1970 , on reguimter member ejections to Comik' Divectur:

-) Camarate IKo

b) Commanater Monimanto

c) Camounh Sang

i) Camanat Teliwetka

lusake. O Ireurems to Cunt' Dimator. 1. 4.70 D. Spatimho NeL

[Doc.\#6]

157 
A I ${ }^{a}$ Região estava paralisada e a crise alastrava-se para a II ${ }^{a}$ Região: a revolução entrava em perturbação por causa de várias razões e dos problemas mal resolvidos no passado. As cartas [em francês e português] dos militantes indicam claramente a indignação da Juventude angolana revolucionaria face a vários problemas: divisões, tribalismo, racismo, etc.

Mas esse problema, em 1972, não era alguma novidade. Dez anos antes, em Outubro de 1962, a liderança do MPLA estava em crise logo que começava as suas atividades nas regiões vizinhas. A reunião da elite do MPLA em Novembro de 1962 provaria isso (A.F.M.S.: 04356.001.013). Fizeram presente nesta reunião: “Agostinho Neto, Mário de Andrade, Viriato Cruz, G. Viana, Matias Migueis, V. Lopes, Videira, C. Pestana, Graças Tavares, Manuel Lima, Eduardo dos Santos, Anibal Melo e Boavida". ${ }^{14}$ Jean-Michel Mabeko-Tali, no seu denso trabalho de Doutoramento, fala com detalhes pertinentes sobre o MPLA perante à si próprio (Mabeko-Tali, 2001-I).

\subsection{Assembleia Extraordinária de Dolisie}

Em Abril de 1972 realizou-se uma Assembleia Extraordinária do MPLA em Dolisie, no Congo Brazzaville, e nos documentos consultados por mim, encontrei o nome de José Eduardo como Presidente da Mesa e Agostinho Neto como vice-presidente da Mesa [ver o Doc.\#7].

Ouvi algumas opiniões que se tratava de Macedo Eduardo dos Santos, o médico. Vários documentos consultados por mim mostram que este médico tinha de fato uma certa influência entre os militantes do MPLA ${ }^{15}$, e entrou algumas vezes em pugilismo com o outro médico, Agostinho Neto. Além das suas claras divergências, importa salientar que MPLA sempre foi um partido de várias divergências paralelas onde as acepções divergentes eram reenquadradas [caso forem construtivas] na ideia principal do "Movimento amplo". ${ }^{16}$

Mas convém especificar que o José Eduardo que participou nesta Assembleia Extraordinária de 1972 era o engenheiro e não o médico. Três razões nos levam a confirmar isso: (i) documentos

14 A observação final é nítida: “a reunião terminou as 6 horas do dia 13/X/1962 num estado de completo desanimo dos seus promotores que tinham a sensação de terem sido enganados e mal compreendidos nas suas intenções de reforçarem o entendimento que se fizera pressentir em Louvanium o debate deviam prosseguir as 18 horas desse mesmo dia mas à hora marcada só estiveram presentes Viera Lopes, Melo, Gentil Viana, Viriato Cruz, Videira e Carlos Pestana que consideraram não se possível realizá-la nessas condições"

15 A.F.M.S.: 04356.001.013; A.N.T.T./PIDES-DGS.

16 Aconselhamos ler as declarações de Mario Pinto de Andrade logo depois da proclamação da independência de RPA (A.F.M.S.). Também, poder se ler: Lara, 1997; Bittencourt, 2008; etc. 
da PIDE indicam que Dr. Eduardo dos Santos estaria já fora da liderança [demitiu-se] desde 1965; (ii) testemunhos oculares consultados por mim especificam que o nome de José Eduardo era reservado ao engenheiro e não ao médico; (iii) de 1968 até 1975, Congo Brazzaville foi uma das regiões laborais do atual Chefe de Estado angolano, e os serviços secretos do colonialismo português - tal como indicam os arquivos nos dias de hoje - mostravam interesse de acompanhar as tensões. 


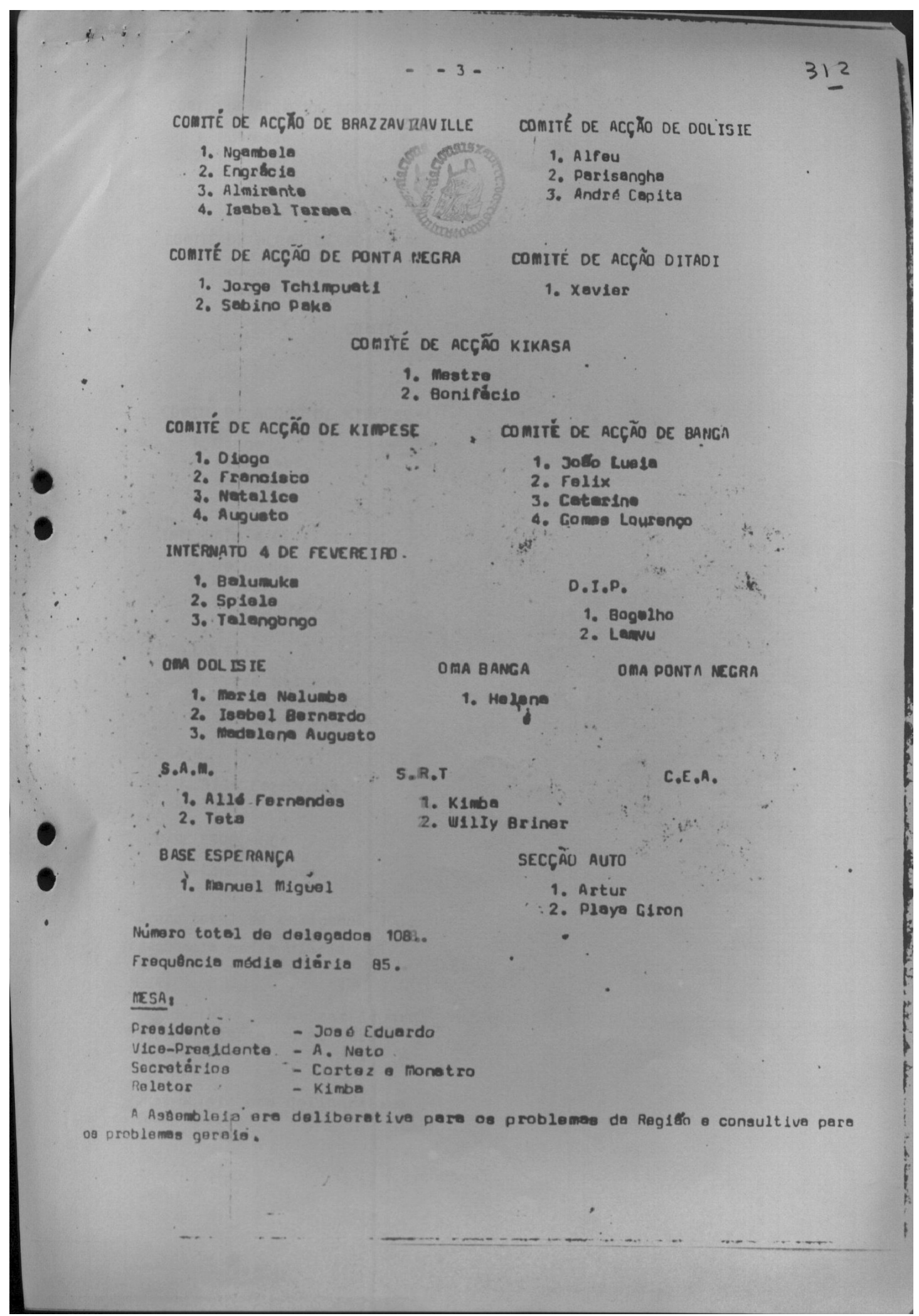

[Doc. \#7]

De acordo com as informações que o governo colonial português teve acesso, a Assembleia Extraordinária Regional de Dolisie foi convocada por, entre outras razões, rever o 
descontentamento de alguns militantes do MPLA face ao Comité Diretor e à liderança de Dr. Agostinho Neto [ver o Doc.\#8].

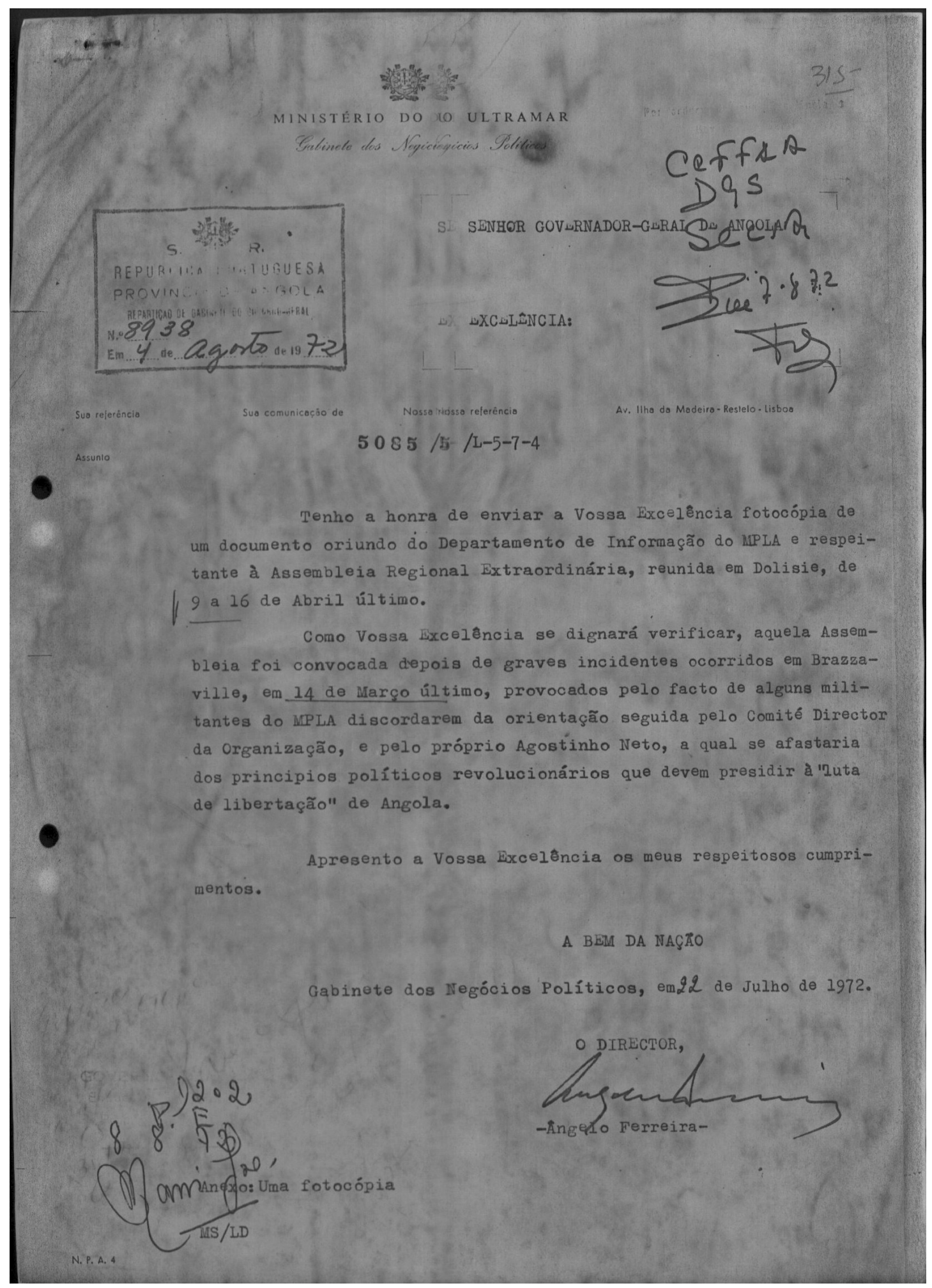

[Doc. \#8] 
Os anexos \#1 [d, e, f] indicam as razões que levaram a realizar a Assembleia Extraordinária de Dolisie: (i) racismo; (ii) tribalismo; (iii) desmobilização dos guerrilheiros; (iv) falta de coesão e amizade [companheirismo]; (v) contrarrevolução nas I ${ }^{\mathrm{a}}$ e II ${ }^{\mathrm{a}}$ Regiões.

Se reunirmos a maior informação contida nos documentos patentes nos arquivos da PIDE/DGS e da Fundação Mário Soares, percebemos quatro pontos levados ao êxito:

(a) O Comité Diretor foi salvo das intempéries políticas e militares

(b) A unidade foi salva em nome da tolerância e disciplina partidária;

(c) O companheirismo poderia afastar índices de racismo e tribalismo;

(d) A formação dos militantes ${ }^{17}$ e guerrilheiros. ${ }^{18}$

De acordo com o que se pode perceber na resolução destes problemas, a assembleia preferiu não abafar a diversidade das acepções, mas insistiu na consolidação de uma liderança forte. Nas orientações finais, percebe-se da disciplina partidária [formação ideológica] e do contexto político da época. Foram optadas decisões draconianas - justificáveis na época - para alcançar os objetivos do MPLA nesta região [ver: Doc.\#9].

Entre 1964-1968, a JMPLA sob égide de José Eduardo optou pela rentabilização dos militantes, através da formação, para melhor fazer face ao colonialismo português. Esse assunto está patente no documento final dessa Assembleia de Dolisie/1972. Por outro, a estratégia de resolver o conflito na base de um amplo diálogo onde todas as vozes emitissem as suas diferentes opiniões [o que requer formação]. Essa metodologia permitiu que se fizesse real radiografia dos problemas pertinentes que perigavam a guerrilha do MPLA naquelas regiões.

Durante sete dias sucessivos, a Assembleia reuniu uma média diária de 85 militantes. No total foram 108 delegados presentes. É preciso antes de tudo considerar dois fatos: (i) desmotivação

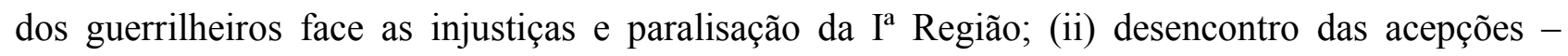

17 Durante o $1^{\circ}$ Congresso do MPLA, José Eduardo dos Santos foi eleito como Secretário do Bureau Político para Educação, Desportos e Cultura. Foi pelo seu interesse nestes domínios.

18 "O exercito de Angola [já com Angola independente] apresentava um quadro bastante triste. Na sua esmagadora maioria, os soldados eram analfabetos, prestavam serviço para receber um salário e ração alimentar. As companhias e os batalhões só podiam contar com todos os soldados quando pagavam os salários ou distribuíam produtos (Conceição, 1999: 111). 
facultado pela realidade regional onde se encontrava o MPLA rodeado das filosofias políticas anticomunistas - desconfortava o Comité Diretor. Com média de 85 militantes diários e durante uma semana, a Assembleia tornou-se num sucesso face a reunificação dos militantes face aos riscos da dissidências. ${ }^{19}$

O perigo foi evitado, por ter disciplinarmente congregado as partes, embora não resolvido na raiz (Mabeko-Tali, 2001-I:276-279). Primeiro, porque era, na gestão humana, necessário que todas as vozes se exprimissem para melhor conhecer o problema. Segundo, para buscar solução na base das evidências e convergir o maior número possível dos constituintes nesta solução como forma de integrar as divergências. Mas tudo na base dos estatutos e disciplina partidários. É assim que interpretei - na primeira instância - os documentos consultados [desde a Assembleia em Dolisie/1972].

\section{Reinterpretação dos documentos}

Ao assumir a presidência da Mesa da Assembleia, sendo Agostinho Neto o seu vicepresidente, o êxito desta Assembleia [evitar dissidência e prevenir separatismos] terá criado um aureolo em José Eduardo dos Santos, que viu [posteriormente] o seu nome mencionado na Comissão de Inquérito criada no fim das atividades. ${ }^{20}$

Em 1972 as relações entre Agostinho Neto e os dirigentes da URSS não eram boas (Milhazes, 2009: 41). Em África, o MPLA encontrava sérios problemas internos que já sabemos quais eram. Ângelo Ferreira faz observar alguns no seu informe (Doc.\#8). Havia, também, problemas externos: isolamento do MPLA face as cláusulas da ONU e da OUA com relação aos apoios logísticos e diplomáticos aos movimentos independentistas. Tiago Morreira Sá conta-nos uma história onde o Keneth Kaunda intervém a favor de Jonas Savimbi junto do presidente americano Gerald Ford, ao detrimento do MPLA de Agostinho Neto (Sá. 2011).

Desta feita, José Eduardo dos Santos na presidência da Mesa da Assembleia pode parecer uma estratégia de aproximar as partes descontentes. Ainda assim, tudo dependeria da capacidade e competência dos integrantes desta mesa de Assembleia. Talvez seja a partir deste exercício que a

19 Mas como nos mostrará Mabeko-Tali (2001), os riscos eram permanentes.

20 Comissão de Inquérito foi constituída por três pessoas: (a) José Eduardo; (b) Ananias; (c) Bogalho. 
URSS tenha começado a esperançar nele (Conceição, 1999: 153), entre vários outros dirigentes treinados de acordo com a ideologia socialista. Este apoio tornar-se-á claro, nos apoios recebidos em 1974 a Brazzaville transitando a partir de Dar-Ès-Salam. ${ }^{21}$ Mas quando assumirá a presidência de Angola, ele incluirá no seu programa e de forma paulatina os E.U.A., tal como o seu antecessor já tinha começado. ${ }^{22}$

Com relação as consequências pós-Assembleia de Dolisie/1972, a figura de José Eduardo [dos Santos] foi aproximada não só do Comité Director com alguma consideração, mas e sobretudo associavam-se a figura de Agostinho Neto com a do jovem José Eduardo na liderança do MPLA, quer para os participantes de Dolisie, quer para os integrantes de outras regiões político-militares. Com relação aos líderes da JMPLA [Daniel Júlio Chipenda, por exemplo], José Eduardo era considerado como obediente/moderado ${ }^{23}$, atencioso/discreto e tecnicista/calculista nas questões politicas e de conflitos.

Nas conclusões da Assembleia de Dolisie, a ossatura solucionadora do conflito interno se apresenta desta forma:
“A acusação não tem fundamento". Na filosofia sobre a resolução dos conflitos, desmentir as acusações em comum acordo, logo no princípio, indica a vontade de salvar o conjunto. É a impressão que se tem aqui sobretudo quando a alínea (b) do ponto 1 [ver Anexo\#1g] recomenda um contacto direto entre a massa e o Presidente do Movimento.

$$
\begin{aligned}
& \text { Os pontos } 3 \text { e } 4 \text { das conclusões desta Assembleia de Dolisie traça uma estratégia } \\
& \text { de engrossar a fileiras do MPLA com proposta de bolsa de estudos: muitos, ao } \\
& \text { ingressar, pensavam beneficiar de alguma bolsa de estudo no Estrangeiro. }
\end{aligned}
$$

Os pontos $5^{\circ}, 7^{\circ}, 8^{\circ}$ evitam estrategicamente os possíveis separatismos, lembrando aos intelectuais e mestiços que devem participar efetivamente em frente do combate. Estes pontos, também, pretendem resolver o problema de

21 Temos uma larga referencia bibliografia com relação a isso, partindo das informações da SCCIA e PIDE/DGS, por um lado. Citar-se-á, para acrescentar, trabalho de pesquisa assídua: Conceição, 1999; Sá, 2011; Milhazes, 2009 ; etc.

22 A partir de Lisboa, o médico e amigo pessoal de Agostinho Neto, de nome Arménio Ferreira (devidamente credenciado), negociava (em 9-16 de Agosto de 1979) com altos dirigentes dos E.U.A. as relações bilaterais com Angola. Depois das prévias negociações com Richard Moose e Donald MacHenry, Zibgnew Bzerzinski (da Segurança do Estado americano) manifestou-lhe a intenção de abrir estas relações. Tudo parou com a morte do presidente A. Neto, por um lado; e por outro, Regean (poder dos republicano) revogou a Emenda Clark, em 1981.

23 Quer dizer não tinha a ambição de conquistar o poder. 
descriminação de classes sociais a partir do Ensino básico.

(4)

O ponto $6^{\circ}$ salvou Agostinho Neto como presidente: este líder explicou-se perante as acusações de exclusão. E a Mesa da Assembleia concluiu que as explicações foram satisfatórias.

Comparar as acusações [a partir de algumas cartas e de testemunhos oculares] com estas conclusões - sem esquecer-se da participação massiva dos militantes nessa Assembleia - leva a construir uma hipótese segundo a qual a competência da Mesa da Assembleia terá partido de uma Autoridade moral ou econômica ou política ou ainda acadêmica perante a massa. Face as acusações diretas ao Dr. Agostinho Neto (que foi vice-presente da Mesa), talvez José Eduardo representasse essa autoridade.

Mas, de facto, que autoridade teria ele? Moral ou econômica? Política ou acadêmica? No mesmo documento, José Eduardo consta na lista da Comissão de Inquérito. Daí, talvez tenha essa autoridade moral. Pela sua formação e onde se formou [Baku/URSS], duas autoridades aqui estariam associadas: acadêmica e política. Com a presença de Agostinho Neto na mesa, acho muito provável que este conjunto dos traços do poder (autoridade moral, acadêmica e política) na pessoa do Presidente da Mesa seria a razão do êxito dessa Assembleia Regional Extraordinária de Dolisie/1972. 


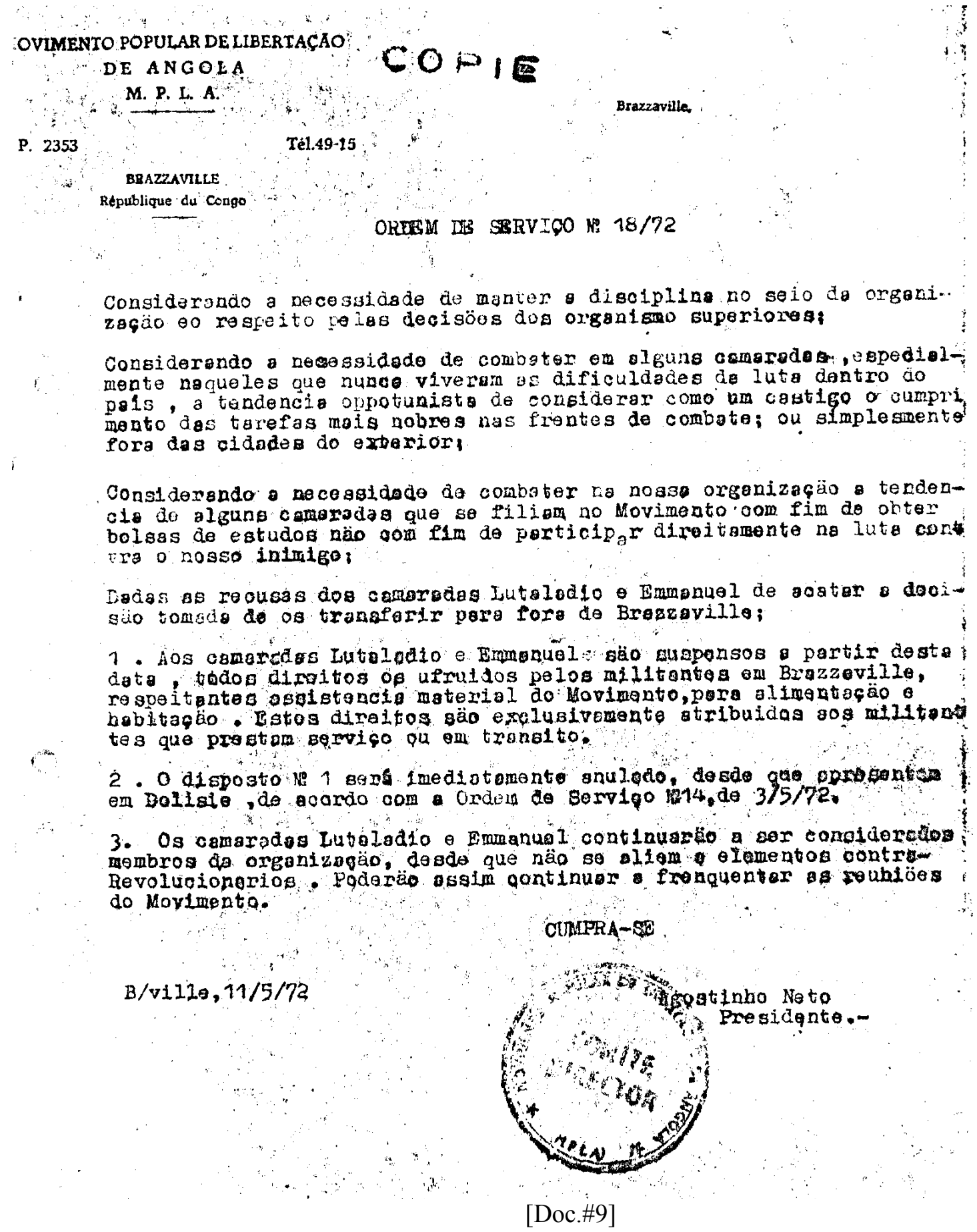

\section{Testamento virtual de Agostinho Neto}

Partindo de hipótese que se deva existir um “testemunho” para legitimar José Eduardo dos Santos para suceder ao poder em 1979, é antes de tudo interessante verificar dois aspectos:

(a) Comparação entre a elite do MPLA presente naquela Assembleia Extraordinária 
Regional em 1972 e a elite do Comité Central do MPLA que elegeu em 1979;

(b) Relação institucional, em 1975/1979, entre a Presidência da república e as pastas ministeriais ocupadas por José Eduardo dos Santos, por um lado. Por outro, o nível de confiança - a título pessoal - entre os dois no mesmo período (1975-1979).

\subsection{Comparação da Elite em duas rupturas históricas}

O quadro a seguir mostra-nos duas realidades produzidas em dois tempos diferentes e nos contextos diferentes.

\begin{tabular}{|c|c|c|c|c|c|}
\hline \multicolumn{3}{|c|}{ Elite na Assembleia Dolisie: 1972} & \multicolumn{3}{|c|}{ Elite na Assembleia do Povo: 1979} \\
\hline política & militar & \begin{tabular}{|l} 
sociocultura \\
$l$
\end{tabular} & política & militar & sociocultural \\
\hline $\begin{array}{l}\text {-Agostinho/Neto } \\
\text { - Tchiwaka (Lúcio Lara) } \\
\text { - Nvunda }\end{array}$ & \begin{tabular}{|l}
-Iko Carreira; \\
- Pedalé \\
•Nzaji, \\
- Pedro Sebastião
\end{tabular} & -Eurico & $\begin{array}{l}\text { - Lucio Lara } \\
\text { - Nvunda }\end{array}$ & \begin{tabular}{|l}
-Pedalé \\
-Iko Carreira \\
-Pedro Sebastião
\end{tabular} & \\
\hline
\end{tabular}

Nota-se aqui que perto de $66 \%$ da elite política, sociocultural e militar que esteve presente na Assembleia Extraordinária de Dolisie em 1972 fez parte, também, do Comité Central e a Assembleia do Povo em 1979 que elegeram José Eduardo dos Santos como presidente do MPLAPT. É compreensível que a Assembleia Extraordinária Regional em 1972 tenha exercido uma certa influência nos órgãos eleitorais do MPLA/Governo em 1979. Mas não limitar-se-ia por aí.

Curioso ainda é que uma percentagem consideráve ${ }^{24}$ dos antigos estudantes da antiga URSS [conferir os Doc.\#1a; 1b; 1c; Doc.\#3; Doc.\#4; Anexo \#2c] participe, como membros do Comité Central, nas eleições partidárias em 10 de Setembro de 1979.

Ao reunir essas informações pensa-se aqui passar a ideia de que a sua eleição como presidente do MPLA-PT - que lhe deu acesso a Presidência da RPA no dia 21 de Setembro de 1979 - parece-nos explicada pela anatomia social dos seus eleitores [oriundos de Dolisie, ou de Brazzaville ou ainda da URSS].

2419 dos 45 titulares no Comité Central. Ver os Doc.\#1a; 1b\#; 1c; Doc.\#3; Anexo \#2c. Pode se consultar, também, os seguintes documentos: PIDE/DGS, proc.1325, nt.200; 


\subsection{Relação institucional entre Presidência e pastas ministeriais}

O ministério das Relações Exteriores de qualquer país é a sua carta de visita nas arenas internacionais de decisão. É um pelouro ministerial do poder (poder financeiro, poder acadêmico/tecnocrático e de prestigio) e requer confidência da Presidência por, entre outras, três razões: (i) segredo do Estado; (ii) lealdade do emissário; (iii) instrumento para mecanizar a geoestratégia do país em termo de relações bilaterais.

Antes da independência de Angola, José Eduardo dos Santos era o coordenador do Departamento das Relações Exteriores e assumiu as funções ministeriais nos dois primeiros anos da RPA (1975-1976). O reconhecimento de Angola para OUA e ONU [durante o seu mandato] levou o Governo do MPLA em colocar, à disposição deste jovem engenheiro das minas, todo capital humano (Paulo Jorge, por exemplo, auxiliando) e livre-trânsito para alcançar vários espaços diplomáticos africanos, asiáticas, americanas e europeias.

Com a ausência física de Agostinho Neto, Angola precisava de alcançar dois grandes objectivos: (i) consolidar as instituições da sua soberania e proteger as suas fronteiras; (ii) garantir a sua independência (política, econômica, cultural...) libertando a África meridional da opressão colonialista para manter boas relações de vizinhança. Em ambos os casos, precisava-se de outra figura já conhecida no mapa diplomático: o perfil de José Eduardo dos Santos - homem de confidência de Agostinho Neto ${ }^{25}$ - terá sido a carta que mais convenceu a maioria quer para fazer face as brisas imperialistas americanas, quer para reconquistar a amizade junto da URSS. ${ }^{26}$

$* * *$

Do ponto de vista do historiador, ainda é difícil localizar este "testamento" enquanto papel/documento que terá deixado o primeiro presidente de Angola para o seu sucessor. Além do MPLA-PT ter as suas regras de sucessão nitidamente diferentes, acho pouco provável que tal

25 o professor Fernando Mourão, que era amigo de Agostinho Neto e que conheceu José Eduardo dos Santos desde Dolisie 1972, partilha essa opinião na sua comunicação durante o Colóquio sobre a "Dimensão Cultural de José Eduardo dos Santos", no II ${ }^{\circ}$ FENACULT 30 de Agosto de 2014.

26 Para perceber o cenário geoestratégia, importa consultar Vladmir G. Shubin cuja obra explica o contexto que se encontrava Angola (Shubin, 2008). Com relação a realidade de Angola, de forma direta a este cenário, aconselhamos os seus autores: Conceição, 1999: 151-155; Milhazes, 2009: 93-95; 111-113; Wright, 2001; Sá, 2011: 57-58; 121. Aconselhamos, também as recolhas registadas pelos serviços de informação do governo colonial português: SCCIA, Proc. Inform. $\mathrm{n}^{\circ}$. 39. Sobre os materiais de guerra que MPLA conseguia: SCCIA, proc. Infor. n. $^{\circ} 47$. 
documento tenha existido e, caso na verdade tenha existido, deve ainda estar guardado num cofre a mil chaves.

Mas pode admitir-se um certo testamento virtual: a aproximação de dois líderes debitaria de forma clara em 1972. Em 1974 a URSS apoia o MPLA através de Brazzaville e José Eduardo dos Santos que lá trabalha será eleito Coordenador das Relações Exteriores, com o apoio de Agostinho Neto. Entre 1975-1976 é ministro das Relações Exteriores. No I Congresso do MPLA em 1977, ele é reeleito Secretário do Bureau Político para Educação, Cultura e Desportos. Perante estes factos, a memória colectiva ou individual tem as suas formas peculiar de registar os factos.

De acordo com Pierre Nora e partindo das nossas análises sobre a História de Angola ${ }^{27}$, a memória sobre os acontecimentos antropomorfiza-se de duas formas: ora apropria-se dos múltiplos espaços onde os factos são consumados; ora expropria-se dos múltiplos agentes que produzem os factos. Nos dois casos, ela dinamiza-se continuamente. Ora a institucionalização desta memória já codificada prende-se nas ferramentas de legitimidade. No caso específico que nos concerne aqui, o testamento indica uma ferramenta de legitimidade urbana [da modernidade] angolana: no passamento físico de detentor do poder, o sucessor é aceite na prova de alguma evidência material.

Assim é, na minha opinião, o caso do testamento virtual que levou os membros do Comité Central a eleger José Eduardo dos Santos em Setembro de 1979, para o cargo de presidente do MPLA-PT. Pode se formular uma tese complementar, partindo da fundamentação do poder. Isto é, só é eleito aquele cujos eleitores reconhecem nele reunir os traços do poder. Ora, Max Weber (1864-1920) e Robert Dahl (1957-) acham que:

"O poder é uma relação entre um qualquer A e um qualquer B, na qual A induz $B$ a agir de um modo que $B$ não faria, senão fosse por acção de $A$. Diz-se então A dispõe ou exerce algum poder sobre B. O poder é uma relação entre actores. Desta forma, o poder que o actor A possui sobre o actor B depende, então, como uma relação desigual, que permite a um actor obrigar outro a praticar uma acção que este não realizaria sem a intervenção do primeiro".

(Barracho, 2008:18).

As características do poder são:

(a) Autoridade: A autoridade moral ou carismática, precisa-se que ela seja legitimada pelas

27 Estamos a referir sobre As origens do reino do Kôngo. 
normas da colectividade.

(b) Prestígio: notoriedade, capital social e cultural que o distinguem da massa populacional.

(c) Domínio: know-how, tecnicidade, capacidade em resolver ou lidar com os problemas que a massa busca solução.

Desta feita, eis os traços da personalidade, que José Eduardo dos Santos trazia com ele na véspera das eleições partidárias em 1979:

(a) Membro do Bureau Político MPLA: capital social/cultural

(b) Membro do Comité Central do MPLA: capital político/acadêmico

(c) Ex-Ministro das Relações Exteriores: capital tecnicista/know-how

(d) Preferido dos Russos: formado em Baku e foi responsável de ajuda logística e militar dos Russo no Congo Brazzaville, na Tanzânia e mesmo em Luanda [em 1974/1975] (SCCIA, infor.\#47; Shubin, 2008; Conceição, 1999; Malhazes, 2009)

(e) Elemento convergente das tradicionais divergências do MPLA: pela seriedade administrativa e gestão humana (arquivos da PIDE-DGS; AFMS).

Com estes traços do poder, ele era o favorito.

\section{Conclusão}

Interessante para nós aqui foi sistematizar estes dados - por demasiado hipotéticos que apareçam - para ver como as fontes [e o método para a sua análise] se comportam por si. A Assembleia de Dolisie/1972, o contexto histórico em 1979 e os traços de poder que José Eduardo dos Santos traziam em Setembro de 1979 elucidam a sua preferência na substituição de Dr. Agostinho Neto no MPLA-PT, e consequentemente como presidente da República Popular de Angola. Pensamos ser este cenário que, nas dinâmicas da memória/história, metamorfosear-se-ia num suposto testamento legitimador que terá deixado o primeiro presidente de Angola. 


\section{Bibliografia}

\section{Arquivos}

SCCIA, “Apoio da Rússia ao MPLA”, cota actual: Pr. Inform. nº 39

SCCIA, “MPLA - Obtenção de material de guerra”, Cota actual: proc. Infor. n. ${ }^{\circ} 4$

PIDE/DGS, “António Agostinho Neto”, proc. \#663, U.I., nº 1423

PIDE/DGS, “José Eduardo dos Santo”, proc. \#

A.F.M.S., “Assembleia Extraordinária Regional da $\mathrm{I}^{\mathrm{a}}$ e $\mathrm{II}^{\mathrm{a}}$ Regiões do MPLA”, pasta\# 04317.002.005 (11 fls).

A.F.M.S., "Relatório do Comité Director à Assembleia Extraordinária Regional da I e II $^{\mathrm{a}}$ Regiões do MPLA” pasta \# 04317.002.006 (8 fls.)

A.F.M.S., “Dossier. Manifestants I ${ }^{\mathrm{a}} \mathrm{II}^{\mathrm{a}}$ Regiões [do MPLA]”, pasta \#04317.001.017 (18 fls.)

\section{Livros sobre Angola}

ANDRADE, M. P., de (1962), Liberté pour l'Angola, Paris: F. Maspero

ANDRADE, M.P. de; OLLIVIER, C., (1974), Guerra em Angola, Lisboa: Serra Nova

ANSTEE. M.J. (1997), Orfão da Guerra fria. Radiografia do colapso do processo de paz angolano 1992/1993, Porto: Campo das Letras

BENDER, G. J., (2004), Angola sob o domínio português - mito e realidade, Luanda: Nzila

BITTENCOURT, M. (1999), Dos Jornais às Armas. Trajectórias da Contestação Angolana. Lisboa: Vega Editora.

BITTENCOURT, M. (2008), “Estamos juntos!” O MPLA e a luta anticolonial, 1961 -1974, Volume I, Luanda: Kilombelombe.

BITTENCOURT, M., (2008), "Estamos juntos!” O MPLA e a luta anticolonial, 1961 -1974, Volume II, Luanda: Kilombelombe

CARREIRA, I. (1996), O pensamento estratégico de Agostinho Neto, Lisboa: D. Quixote

CONCEIÇÃO, J. M. N. P., (1999), Angola: uma Política Externa em Contexto de Crise (19751994), São Paulo: Tese de Doutorado em Ciência Política na FFLCH/USP

GONÇALVES, J. (1991), Angola a fogo intenso, Lisboa: Cotovia 
MABEKO-TALI, J.M., (2001) Dissidências e poder de Estado: o MPLA perante si próprio. Vol I (1962-1974), Luanda: Editorial Nzila.

MABEKO-TALI, J.M., (2001), Dissidências e poder de Estado: o MPLA perante si próprio. Vol II (1974-1977), Luanda: Editorial Nzila

MILHAZES, J., (2009), Angola: o princípio do fim da união Soviética, Lisboa: Nova Veja.

PACHECO, C., (2010), Angola: Um gigante com os pés de barro, Lisboa: Veja

SÁ, T.M. (2011), Os Estados Unidos e a Descolonização de Angola, Lisboa: Dom Quixote

SANGO, A.O.J., (1996), “Angola - uma tentativa de acomodação das diferenças", in: II RIHA, pp.131-146

SHUBIN, V. G. (2008), The Hot Cold War - The USSR in Southern Africa, London: Pluto Press

STOCKWELL, J. (1979), CIA contra Angola, Lisboa : Ulmeiro

WALTERS, R.M., (1973), Racism and revolution: a case study of Angola, Simon Fraser University (Dissertação de Mestrado em Political Science, Sociology and Anthropology)

WRIGHT, G. (2001), A destruição de um Pais - A política dos Estados Unidos para Angola desde 1945, Luanda: Nzila

\section{Livros sobre África}

APPIAH, A.K., (2010), In my Father's House. Africa in the philosophy of culture, New York: Oxford University Press

BATSîKAMA, P. (2014c), "Estado-nação em África. Congo-Brazzaville Congo-Kinsâsa”, In: Revista Africa[s], Universidade Estadual de Bahia - UNEB, \#2, II ${ }^{\circ}$ Semestre.

BÉNOT, Y. (1969), Idéologies des independances africaines, Paris: François Maspero [cahiers libres 139-140].

\section{Livros gerais}

BARRACHO, (2008), Poder, autoridade e liderança, Lisboa: Universidade Lusíadas Editora BORDIEU, P. (1996), Raisons pratiques sur la théorie de l'action, Paris: Points

WEBER, M., (2011[1964]), L'étique protestante et l'esprit du capitalisme, Paris: Plon 